\title{
STAT2 wt Allele
}

National Cancer Institute

\section{Source}

National Cancer Institute. STAT2 wt Allele. NCI Thesaurus. Code C52152.

Human STAT 2 wild-type allele is located within $12 q 12-12 q 14$ and is approximately $18 \mathrm{~kb}$

in length. This allele, which encodes signal transducer and activator of transcription 2

protein, is involved in interferon signaling. 